\title{
AN EVALUATION OF WHOLESALER ACCURACY IN JUDGING THE LEGALITY OF SELECTED ACTIVITIES
}

\author{
Robin T, Peterson \\ New Mexico State University \\ Las Cruces, NM
}

\begin{abstract}
Wholesalers are subject to a wide variety of edicts at the federal, state, and local levels. This paper sets forth the results of an inquiry into the degree of knowledge held by a sample of wholesalers with regard to various major federal laws. A mail survey requested respondents to indicate their degrees of belief in the legality of a number of commercial practices. An analysis of the results, in total and by size of firm, resulted in various conclusions on perceptions of legality in this sector.
\end{abstract}

\section{Background}

The inquiry pursued in this paper assesses the degree to which wholesale managers are familiar with important federal laws. The paper addresses the importance of this topic and highlights some wholesale activities that are especially vulnerable to regulation. In addition, it discusses changes in the regulations and the status of small wholesalers as regards the law. In addition, it looks at the importance of the topic to manufacturers. Finally, it presents an empirical analysis of managerial cognizance of the federal laws.

Wholesaler knowledge of federal law is a topic that deserves study. Are these managers aware of the constraints which legislators place upon them? It is possible that many are not aware of the depth of their knowledge regarding this subject and mistakenly believe that they can judge which practices are compatible with the law and which are not. If this were the case, these managers are rendering themselves vulnerable to possible prosecution and a number of corollary consequences. It follows that wholesale managers could benefit by becoming aware of the state of their legal knowledge in relation to federal regulation.

Wholesalers are an essential component of many marketing channels. Manufacturers, retailers, and industrial buyers have found that these entities are required because they perform a variety of necessary functions both effectively and efficiently. Manufacturers who utilize wholesalers in the channel should be aware of legal problems that can materialize in the process of employing these intermediaries for distribution and related functions. If wholesale managers are violating the law, they may involve their suppliers in lawsuits and find that these activities must be altered, due to unexpected legal edicts. Hence, it is in the interest of manufacturers that wholesale managers be familiar with the law. 
Wholesalers are confronted with a robust and expanding volume of federal regulations which affect their activities. The regulations have an impact on an extensive number of the strategies and tactics which the enterprise might undertake. There are restrictions on advertising, personal selling, sales promotion, hiring and promoting employees, dealing with suppliers, collusion with rivals, pricing, and numerous other activities (Wiesendanger, 1993; Apaiwongse, 1993). An especially consequential area of the law relates to price fixing. A multi-state plumbing wholesale firm, for instance, was charged with engaging in a conspiracy to suppress and restrain competition by raising, fixing, and maintaining prices for the sale of wholesale plumbing supplies ("Price Fix in Texas," 1995). Legal expenses for the firm were almost a million dollars and the court ruled against the defendant company.

Alterations over time in the laws and in the ways they are implemented obfuscates the regulatory climate (Department of Justice, 1992; Hunter, 1993). These changes require wholesalers to continuously moniter new regulations which federal authorities might adopt or have already brought into play (Hollander \& Popper, 1994; Siebert, 1992). Some recent court rulings, for example, have illustrated that interpretations of what constitutes damages to a wholesaler under the Robinson-Patman Act have been amended with the passage of time ("Failure to Show," 1995).

Managers who work for smaller wholesalers are confronted with an especially severe burden (Heide, 1994). Local and regional managers who are employed by larger concerns are not accountable for some activities that the federal government regulates such as buying and advertising, many of which are centered at the corporate or division level (Bunn, 1993; Robicheaux,1994). But executives in smaller concerns have a much more extensive range of responsibilities. In addition, large wholesaler managers often have recourse to specialized attorneys which the company retains (Bellhouse \& Hutchison, 1993; "Franchising Currents," 1993). This condition is less common for smaller companies.

The laws can influence numerous wholesaling functions, are sometimes unclear, and may impose severe consequences to the firm (Plaisance, 1997; Budden, Jones \& Budden, 1996). Hence, wholesalers are well-advised to remain informed on the nature of these constraints and how federal authorities implement them (Himelstein, 1993). Wholesalers require insights into legislation to avert possible damage awards, injunctions, fines, legal fees, out-of-court settlements, and even imprisonment (Hukill, 1990; Bowers, 1991; Swift \& Kent, 1994).

Manufacturers who employ wholesalers may subject themselves to legal liabilities and loss of goodwill when the latter commit legal infractions (Arreda \& Hovenkamp, 1989). In certain instances, courts may rule that the wholesaler was acting as the agent of the manufacturer, legally binding the manufacturer for the actions of the wholesaler (Boyd, Walker \& Larreche, 1998). Hence, unwitting producers can subject themselves to vulnerability, even though they are not directly responsible for the actions that gave rise to the litigation. Illegal actions by 
wholesalers also can result in unfavorable publicity for the manufacturer, especially when the details are heavily publicized in the media.

Wholesale managers cannot, of course, be expected to be conversant with all aspects of relevant legislation. Rather, thorough comprehension of the law is better placed in the responsibilities of attorneys employed by or retained by the company (Areeda \& Hovenkamp, 1989). On the other hand, wholesalers should have some comprehension of the more significant legislation and court rulings and be alert to situations where attorneys should be retained (Bloom, Milne, \& Adler, 1994; Wisconsin Music Network, 1993; "Commercial Litigation," 1992).

Trade and professional organizations can have an impact on enhancing the knowledge of wholesalers regarding practices that are legally sensitive. These organizations can provide insights through publications and seminars that will be useful to wholesale managers. In some cases, such organizations can take on a proactive role and attempt to influence legislators to change the law, where such alteration appears to be needed.

This inquiry explored the extent to which a sample of wholesalers could correctly differentiate between illegal and legal actions. It also scrutinized differences in perceptions of legality between managers employed by large and small wholesalers. A sample of wholesale managers received a list of written activities and were asked to examine the list and to specify the extent to which they believed each one to be illegal or legal. The analysis also examined the degree to which these perceptions were or were not correct.

Two hypotheses were subjected to test:

Hypothesis 1: Wholesalers will be able to correctly identify, as legal or illegal, fifty percent or more of a list of actions that are potentially illegal.

Hypothesis 2: Small wholesalers will be less accurate than large wholesalers in judging the legality of actions that are potentially illegal.

\section{The Inquiry}

The researchers mailed cover letters and questionnaires to 500 randomly-selected managers of wholesale firms. The sample frame was made up of telephone book yellow pages from 17 large and geographically-dispersed cities throughout the continental United States. The letters were addressed to the senior marketing officer at each wholesale unit. Where a senior marketing manager did not exist, the letters were addressed to the general manager.

Approximately one week before obtaining the questionnaire, each manager received a postcard which requested participation in the inquiry and mentioned that a questionnaire would soon arrive in the mail. The instructions requested 
completion of the questionnaires and their return in postmarked preaddressed envelopes. One hundred-forty-one usable completed questionnaires were derived from this initial mailing. A follow-up postcard and a second questionnaire were forwarded to wholesalers that did not respond. This wave provided sixty-eight additional usable completed questionnaires. The final sample size was 209 , producing a response rate of $41.8 \%$.

The questionnaire asked the respondents if their annual sales over the past two years had exceeded $\$ 2$ million. Those with revenues exceeding this figure were categorized as "large wholesalers" while those with $\$ 2$ million or less were categorized as "small wholesalers"'. The sample resulted in 73 large and 136 small wholesaler respondents.

The questionnaire described twenty actions that wholesale managers might take in the course of their daily work. The researchers carried out a content analysis of six chapters relating to laws, ethics, and social responsibility appearing in four top-selling channels of distribution books as a source of the actions ${ }^{2}$. These represented activities that were either illegal or potentially unethical, depending on the circumstances surrounding the actions.

One-half of the actions are specifically in violation of federal laws or have been interpreted as such by the courts. The appendix describes each action. These descriptions were furnished to the members of the sample so that they might comprehend exactly what the listed actions meant. The other half of the actions were not in violation of the federal laws although some wholesale managers might see them as unethical.

The respondents were asked to specify their opinion of the legality of the actions on a five-point scale that was anchored by the terms "obviously illegal," "probably illegal," "gray area," "probably legal," and "obviously legal" measured against federal laws. The respondents were only asked to respond to the legality question. They were not asked to judge the degree to which the actions were ethical or unethical. The hypothesis was that the wholesalers, as a group, would correctly identify the legal status of fifty-percent or more of the twenty actions. Fifty-percent was chosen because it is the most neutral proportion available and, by default, marks the mid-point between what might be construed as "naive," on the one hand and "knowledgeable," on the other. This percentage has been employed in other studies of perceptions of the assessment of the legality of business practices (Peterson, 1998).

The tabulation process involved assigning quantitative values to the five elements in the scale. These values ranged from five (for "obviously illegal") to one (for "obviously legal"). The assigned values in each class were multiplied by their respective frequencies to derive arithmetic means for each of the twenty actions. Hence, a mean value of two for a specific action would signal that the sample members felt that action was "probably legal." Table 1 lists the mean values for each of the twenty actions. 
Table 1

Wholesaler Perceptions of the Legality of Various Actions

\begin{tabular}{llcc}
\hline \multicolumn{1}{c}{ Action* } & $\begin{array}{c}\text { Mean Scale } \\
\text { Value }\end{array}$ & $\begin{array}{c}\text { Actual Legal } \\
\text { Status }\end{array}$ & $\begin{array}{c}\text { Std. } \\
\text { dev. }\end{array}$ \\
\hline Price collusion with competitors & 3.6 & Illegal & .27 \\
Charging higher prices than rivals & 2.2 & Legal & .14 \\
Hiring only experienced help & 2.0 & Legal & .15 \\
Predatory pricing & $2.4^{* *}$ & Illegal & .12 \\
Disparaging a competitor's integrity & 3.1 & Illegal & .21 \\
Charging the same price to similar buyers & 1.9 & legal & .13 \\
Suggest that customers buy an item now & 2.1 & Legal & .12 \\
Agree to divide market with rivals & $2.2^{* *}$ & Illegal & .11 \\
Steal trade secrets & 4.1 & Illegal & .25 \\
Tell customers they are getting a & & & \\
$\quad$ price break when this is untrue. & $2.0^{* *}$ & Illegal & .13 \\
Sell a low quality product & 2.1 & Legal & .10 \\
Aim the marketing effort only on larger customers & $3.7^{* *}$ & Legal & .28 \\
Sell products in throw-away & & & \\
$\quad$ non-degradable containers & 1.7 & Legal & .11 \\
Preempt potential competition with & & & \\
$\quad$ prices below costs & $2.3^{* *}$ & Illegal & .13 \\
Inducing price discrimination & $2.0^{* *}$ & Illegal & .15 \\
Selling unsafe products & 4.4 & Illegal & .21 \\
Having directors on the boards of & & & \\
$\quad$ directors of competitors & $2.3^{* *}$ & Illegal & .22 \\
Using comparative advertisements & $3.8^{* *}$ & Legal & .25 \\
Discriminating in price when this can be & & & \\
$\quad$ justified by cost differences & $3.7^{* *}$ & Legal & .26 \\
Ignoring a manufacturer's suggested price & 1.4 & Legal & .09 \\
\hline
\end{tabular}

* The questionnaires described each action in detail.

** Indicates that respondents' mean value on the legality of an activity was in error. Significant differences between mean values and 3.0 were assessed by Tukey $K$ tests at the .05 level.

According to the data in the table, the sample members incorrectly perceived the legality of nine actions. These were:

1. Predatory pricing.

2. Agree to divide market with rivals.

3. Tell customers they are getting a price break when this is untrue.

4. Aim the marketing effort only on larger customers.

5. Prempt potential competition with prices below costs.

6. Inducing price discrimination. 
7. Having directors on the boards of directors of competitors.

8. Using comparative advertisements.

9. Discriminating in price when this can be justified by cost differences.

Six of the incorrectly judged actions are illegal but the respondents judged them to be legal. Conversely, only three of them were legal but were judged to be illegal. The main bias, then, is in the direction of being unaware of federal laws instead of incorrectly interpreting that various actions are not in compliance.

The wholesalers made correct judgments in eleven cases. Thus, they correctly identified 55 percent of the legality associations, thereby providing support for the first hypothesis. However, the data shows that they have insights into only slightly better than half of the constraints which federal statutes impose. Their collective response was wrong in 45 percent of the cases and these mistaken perceptions are in the domain of regulations which are associated with severe penalties, such as large fines, restrictive injunctions, and even possible imprisonment.

Interestingly, all of the incorrect judgments but one (using comparative advertisements) pertain to antitrust legislation, assuming that the Federal Trade Commission Act is included in that category. Given the significant penalties that antitrust laws impose, misperceptions relating to these laws can be very costly to the company.

Five of the actions which the respondents judged incorrectly relate to the pricing function. It appears that there is considerable lack of insight on laws which pertain to this activity - a very critical one in the marketing strategies of numerous wholesalers.

Another major portion of this study required analyzing the responses by size of company. It was hypothesized that managers from larger wholesalers would correctly identify the legal status of a larger number of actions. One reason for this is that large companies tend to be more highly scrutinized by federal authorities. Management can be expected to be aware of this condition and to inform themselves about the regulations as a means of reducing the probability of prosecution or fines. Another reason is that managers in larger companies are more likely than those in smaller companies to specialize in management functions per se and be familiar with laws relating to such duties. In smaller companies, managers are more likely to have nonmanagerial duties. To the extent that these duties consume time and effort, management is less able to have the resources necessary to become aware of legal requirements. Finally, larger wholesalers are more likely than small wholesalers to have formal training programs in areas such as legal issues.

Table 2 sets forth data on perceptions of the legality of wholesaling actions, categorized by size of firm. The same test of significance as was employed in Table 1 was applied to the data in Table 2 . In addition Tukey $k$ tests were made to assess the significance of the differences between scores for large and small firms. In order to directly address the hypotheses, only those differences which take place when large and small firms, as a group, differ on the legality of the practices 
are meaningful. Where such differences occur, they reinforce the assessment of the hypotheses.

Table 2

Wholesaler Perceptions of the Legality of Various Actions by Size of Retailer

\begin{tabular}{|c|c|c|c|c|}
\hline \multirow{2}{*}{ Action* } & \multicolumn{2}{|c|}{ Mean Scale Values } & \multirow[b]{2}{*}{$\begin{array}{l}\text { Actual Legal } \\
\text { Status } \\
\end{array}$} & \multirow[b]{2}{*}{$\begin{array}{l}\text { Std } \\
\text { dev }\end{array}$} \\
\hline & $\begin{array}{l}\text { Large } \\
\text { Firms }\end{array}$ & $\begin{array}{l}\text { Small } \\
\text { Firms }\end{array}$ & & \\
\hline Price collusion with competitors & 3.8 & $3.2 \#$ & Illegal & .19 \\
\hline Charging higher prices than rivals & 2.0 & $2.6 \#$ & Legal & .13 \\
\hline Hiring only experienced help & 2.0 & 2.0 & Legal & .15 \\
\hline Predatory pricing & 2.8 & $2.2^{* * \#}$ & Illegal & .17 \\
\hline Disparaging competitor's integrity & 2.9 & 3.3 & Illegal & .21 \\
\hline Charge same price to similar buyers & 1.5 & $2.7 \#$ & Legal & .18 \\
\hline Suggest customers buy item now & 2.1 & 2.1 & Legal & .14 \\
\hline Agree to divide market with rivals & 2.6 & $2.0 * * \#$ & Illegal & .12 \\
\hline Steal trade secrets & 4.3 & $3.7 \#$ & Illegal & .24 \\
\hline $\begin{array}{l}\text { Tell customers they are getting a } \\
\text { price break when this is untrue }\end{array}$ & $2.4^{* *}$ & $1.8^{* * \#}$ & Illegal & .08 \\
\hline Sell a low quality product & 2.0 & 2.2 & Legal & .15 \\
\hline $\begin{array}{l}\text { Aim the marketing effort only on } \\
\text { larger customers }\end{array}$ & $3.6 * *$ & $3.8 * *$ & Legal & .21 \\
\hline $\begin{array}{l}\text { Sell products in throw-away } \\
\text { non-degradable containers }\end{array}$ & 1.6 & 1.7 & Legal & .09 \\
\hline $\begin{array}{l}\text { Preempt potential competition with } \\
\text { prices below costs }\end{array}$ & 2.9 & $2.0^{* * \#}$ & Illegal & .14 \\
\hline Inducing price discrimination & $2.2 * *$ & $1.9 * *$ & Illegal & .16 \\
\hline Selling unsafe products & 4.4 & 4.4 & Illegal & .24 \\
\hline Having directors on the boards & & & & \\
\hline of directors of competitors & 2.9 & 2.0 & Illegal & .15 \\
\hline Using comparative advertisements & 3.0 & $4.2 * *$ & Legal & .26 \\
\hline $\begin{array}{l}\text { Discriminating in price when this can be } \\
\text { justified by cost differences }\end{array}$ & 3.5 & $3.8 * *$ & Legal & .20 \\
\hline Ignoring a manufacturer's suggested price & 1.3 & 1.6 & Legal & .15 \\
\hline
\end{tabular}

* The questionnaires described each action in detail.

** Indicates that respondents' mean value on the legality of an action was in error. Significant differences between mean values and 3.0 were assessed by Tukey $k$ tests,, 05 level.

\# Indicates action scores that are significantly different for small and large firms at the .05 level, according to a Tukey $k$ test.

The mean scale values in Table 2 confirm the hypothesis that wholesale managers of small companies are less accurate in their perceptions than those of large 
companies. In the large firm sample, only three of the mean scale values signify inaccurate perceptions by the respondents. The corresponding number of erroneous mean perceptions for small wholesalers is eight. Fifteen percent of the practices evaluated by large wholesale managers and forty percent evaluated by small wholesaler personnel were in error. Further, for activities where both large and small companies are in error, the mean scale values for the smaller companies were further away in magnitude from the correct response. It is apparent that the larger company managers possessed a superior knowledge of the federal laws and their application.

\section{Summary and Conclusions}

The goal of this inquiry was to measure the degree to which a sample of wholesale managers employed by large and small companies could correctly differentiate between illegal and legal actions, as prescribed by federal laws. In the full sample the wholesaler managers were able to correctly identify the legality of the actions in fifty five percent of the cases. A comparison between large and small wholesalers indicated that small wholesale managers were less accurate than large wholesale managers in identifying legal and illegal actions.

The inquiry suggests that wholesale managers, particularly those employed by smaller firms, are in need of more supervision, training, and education in federal regulation of marketing actions. If firms do not attain this, they and their managers are subject to governmental prosecution and lawsuits levied by customers, rivals, and others.

Smaller wholesalers tend to be less familiar with the regulations, since they have limited staffs and are pressed for time. There are, however, several courses of action which they can pursue which will be neither costly nor time consuming. One is to subscribe to and read industry trade association bulletins and newsletters. Many of these are useful in pointing out trends and new developments in the legal field. Another approach is to retain an attorney on a contractual approach, where a nominal sum is given to the attorney each month, in return for legal advice, when needed. Finally, many community colleges, colleges, and universities offer summary courses and seminars which cover aspects of the law that are relevant to business managers. Many of these offerings provide valuable insights on matters such as practices which are likely to be in violation of the law and when to utilize an attorney.

This study focused only upon federal regulations. However, it is possible that wholesale managers are equally ill-informed on the legality of business practices in light of state and local regulations. Further inquiries which analyze the state of knowledge regarding these constraints would be useful.

Managers in wholesale firms are well-advised to measure the degree to which they have knowledge of federal, state, and local regulations. Other laws, in addition to those studied in this paper, could be covered by the measurement effort, 
depending on the specific legal environment confronting the firm. If the analysis reveals shortcomings in knowledge, remedial measures could be pursued to correct the shortcomings. These could include consulting with knowledgeable attorneys, reviewing business law texts and journals, and enrolling in classes and management development seminars. The result of well-conceived efforts could be actions that are more in congruence with the continually expanding depth and scope of regulation.

Beyond informing themselves about the relevant laws, wholesale managers are well-advised to take steps resulting in legal insights on the part of key employees. These individuals can easily pursue actions that violate the statutes, creating major problems for the company. Key employees should have insights into the provisions of the laws and be aware that management is strongly motivated to avoid legal entanglements.

Manufacturers who use wholesalers should take steps to minimize the risk that the latter commit actions which legally bind or cause loss of goodwill for producers. This includes careful screening of potential wholesale channel members, monitoring of their activities which might violate laws, and careful supervision of their day-to-day actions (where this is practical).

1 Large and small wholesalers are defined in different ways by different sources. The definitions used by the Federal Reserve, the U.S. Employment Service, the Committee for Economic Development, and the Small Business Adminstration all differ. This paper uses the $\$ 2$ million annual sales figure as the criterion is relatively common (See Peterson \& Koorisparian, 1997).

2 1. Bowersox, Donald \& M. Bixby Cooper, Strategic Marketing Channel Management. New York: McGraw-Hill, 1992.

2. Berman, Barry, Marketing Channels. New York: Wiley, 1996.

3. Rosenbloom, Bert, Marketing Channels: A Management View. Dryden Press, 1995.

4. Stern, Louis W. \& Adel I El-Ansary. Marketing Channels. Englewood Cliffs, NJ: Prentice-Hall, 1992.

\section{Appendix \\ Written Description of the Actions Assessed}

1. Price collusion with competitors: Making agreements with rival wholesalers which stipulate the prices each competitor would charge to its customers.

2. Charging higher prices than rivals: Assessing company customers higher prices than those assessed by competitors to their customers.

3. Hiring only experienced help: Hiring only those job applicants who have personal experience in wholesaling work. 
4. Predatory pricing: Setting company prices at low levels in order to drive competitors out of business.

5. Disparaging a competitor's integrity: Spreading false rumors that a competitor overcharges customers.

6. Charging the same price to similar buyers: Charging identical prices to different company customers when these customers are essentially alike in terms of the costs of serving them.

7. Suggest that customers buy an item now: Urging immediate purchase as prices may rise sometime in the future.

8. Agree to divide market with rivals: Reach an agreement whereby you will not compete for certain customers reserved for competitors and they will not compete for certain markets reserved for your firm.

9. Steal trade secrets: Acquire important confidential information possessed by rivals, without their knowledge or consent.

10. Tell customers they are getting a price break when this is untrue: Falsely informing customers that they are receiving a price that is lower than that charged to other customers.

11. Sell a low quality product: Sell a product that is inferior in performance, materials, or workmanship to products sold by competitors.

12. Aim the marketing effort only on larger customers: concentrate your marketing personnel and activities on satisfying the needs of your larger customers.

13. Sell products in throw-away non-degradable containers: Sell goods in packages that will not break down into natural commodities in a reasonable period of time.

14. Prempt potential competition with prices below costs: Keep new firms from entering your market by pricing below costs, making it impossible for new firms to make a profit.

15. Inducing price discrimination: Persuading a supplier to sell goods to you at a lower price than that paid by a similarly situated competitor.

16. Selling unsafe products: Offering for sale goods that could damage the health or safety of users.

17. Having directors on the boards of directors of competitors: Using as direc- 
tors, individuals who are also on the board of directors of one or more rivals.

18. Using comparative advertisements: Pointing out, in advertisements, that your products are superior to those carried by competing firms.

19. Discriminating in price when this can be justified by cost differences: Charging different prices to different customers when the costs of serving the customers is different.

20. Ignoring a manufacturer's suggested price: Selling above or below the price suggested by the supplier of the goods.

\section{References}

Apaiwongse, T.S. (1993). Market responses to EPA policies. Industrial Marketing Management. 22, 319-330.

Areeda, P. E., \& Hovenkamp, H. (1989). Antitrust law 1989 supplement. Boston: Little, Brown, and Company, 234-248.

Bellhouse, A. E., \& Hutchison, G. M. (1993). A model for the analysis of distribution channels. Marketing Intelligence and Planning Journal. 11, 22-27.

Bloom, P. N., \& Milne, G. R., \& Adler, R. (1994). Avoiding misuse of new information technologies: Legal and societal considerations. Journal of Marketing. 58, 98-110.

Boyd, H. W., Jt., Walker, O. C., Jr., \& Larreche, J. C. (1998). Marketing management. Boston: Irwin McGraw-Hill, 62.

Bowers, D. K. (1991). The privacy challenge. Marketing Research. 11, 37-49.

Budden, M. C., Jones, M. A., \& Budden, C. B. (1996). Supplier relationships and the trade secrets dilemma. Journal of Purchasing and Materials Management, 32, 45-49.

Bunn, M. (1993). Taxonomy of buying decision approaches. Joumal of Marketing. 57, 38-56.

Commercial litigation. (1992). Law Reporter, 35, 254-259.

Department of Justice adopts picot program for United States business review procedures. CCH.150,095, (Dec. 1992), 4.

Failure to show lost sales prompts court to eject distributor's r-p damages. (1995). BNA Antitrust \& Trade Regulation Report. 69(1728), 275. 
Franchising currents. (1993). Franchise Law Journal 13, 49-55.

Heide, J. B. (1994). Inter-organizational governance in marketing channels. Journal of Marketing, 58, 71-85.

Himelstein, L. (1993), Should business be afraid of juries? BusinessWeek, 3345, 100-101.

Hollander, S. C., \& Popper, K. M. (1994). Balkanization of America: Lessons from the interstate trade barrier experience. Journal of Macromarketing, 14(2), 62-72.

Hukill, C. (1990). Significant decisions in labor-law. Monthly Labor Review, 113, 52-55.

Hunter, B.T. (1993). Will beefed up inspection assure food safety? Consumers' Research. 73, 17-21.

Peterson, R. (1998). An assessment of the accuracy of independent retailer judgment of the legality of selected commercial practices. Journal of Business and Economic Perspectives, 14, 32-41.

Plaisance, S. (1997). Where credit is due: Study gives affirmative action hires their day of reckoning. The Joumal of State Govemment, $70,2-6$.

Price fix in Texas. (1995). Contractor, 42, 5-9.

Robicheaux, R. A. (1994). The structure of marketing channel relationships. Journal of the Academy of Marketing Science $22,38-51$.

Siebert, B. (1992). Downsizing. An overview of legal considerations. Labor Law Journal, 43, 483-487.

Swift, C.O., \& Kent, R.L. (1994). Sexual harassment: The issues and guidelines. Journal of Marketing Education, 16, 3-14.

Wiesendanger, B. (1993). Last call. Sales and Marketing Management. 145, 62-67.

Wisconsin Music Network v. Muzak Ltd. (1993). 5F. 3rd. 218 (7th Cir.)

Robin T. Peterson is the Norwest Bank Distinguished Professor of Marketing at New Mexico State University. He received the Ph.D. in marketing from the University of Washington in Seattle. He has produced a number of articles and books in the areas of marketing, retailing, wholesaling, business ethics, forecasting and small business. 